\title{
Eco-Islam: Beyond the Principles of Why and What, and into the Principles of $\mathrm{How}$
}

\author{
Dina M. Abdelzaher, Ph.D. \\ University of Houston Clear Lake (USA) \\ abdelzaher@uhcl.edu
}

Amr Kotb, Ph.D. ${ }^{1}$

Prince Sultan University (Saudi Arabia) and Cairo University (Egypt)

kotb.amr@gmail.com

\begin{abstract}
Akrum Helfaya, Ph.D.
Keele University (UK) and Damanhour University (Egypt)

a.n.ekara.helfaya@keele.ac.uk
\end{abstract}

\begin{abstract}
This is the final peer reviewed version of the following paper: [Abdelzaher, D., Kotb, A. \& Helfaya, A. (2017). Eco-Islam: Beyond the Principles of Why and What, and Into the Principles of How. Journal of Business Ethics], which has been published in final form at [DOI: 10.1007/s10551-017-3518-2]. This paper may be used for non-commercial purposes in accordance with Springer terms and conditions for self-archiving.
\end{abstract}




\title{
Eco-Islam: Beyond the Principles of Why and What, and into the Principles of How
}

\begin{abstract}
A growing body of literature has thought to draw the link between Islamic ethics and environmental stewardship to explain the foundational principles of why humans should care about the environment, which gave rise to the coining of the term "Eco-Islam". But only recently have we started to witness the birth of empirical examinations of the Eco-Islam concept, going beyond the why principles and so explaining what is meant by the environment, the role of humans towards it, and its regard as explained in the holy book of Muslims - the Qur'an. However, these foundational (why and what) principles do not suggest specific behavioural actions. This study conceptually and methodologically advances the existing literature from the belief (why and what) level of Islamic teachings about the environment to the action level by addressing questions such as: how can we take our belief of "Eco-Islam" to actually guide behaviours and outcomes? And in which business contexts are these behavioural principles more immediately applicable? To achieve this, we have undertaken qualitative research to analyse the content (i.e. verses) of the holy Qur'an. Our findings yield a framework that proposes key behavioural application principles (how) of Eco-Islam. Examples of practical applications of the framework and policy implications are discussed.
\end{abstract}

Key words: Islam, Environment, Eco-Islam, Individual Responsibility, Islamic Environmental Responsibility, Sustainability. 


\section{Introduction}

The role of Islam could be one of the decisive factors tipping the planet towards a sustainable future. This commitment in Istanbul to a low carbon future can be of historic significance in the path to resolving climate change and other pressing environmental issues.

(Assistant GS of the UNDP, Olav Kjorven 2009)

The world's population is facing various growing and severe environmental crises (e.g. greenhouse gas emissions, unbridled ecological devaluation, water scarcity, air/water pollution, land degradation, soil depletion, biodiversity loss, eroded ozone layer, etc.), which are threatening life on earth (Beck 1992, 1999; Farman 1990; Schneider 1990; Stern 2006; Wilkinson and Woodin 1990). Given the immense scale of these environmental problems caused by humankind and the shortcomings of the corporate environmentalism approaches, there is a need for urgent action if the environment is to be preserved at all (Adams 1990; Jones 2010; Kovel 2007). This desperate environmental state has raised the call for novel complementary, rather than alternate, approaches for promoting environmental ethics, with special reference to the powerful role of religions (Iyer 2009; Owen and Videras 2007; Videras et al. 2012; Williams and Zinkin 2010). While formal regulation is important, religious belief systems can offer more influential guidance for moral values (Brammer et al. 2007), which in turn shape individual attitudes towards the environment (Bubna-Litic 2009; Hui 2008; Owen and Videras 2007).

While prior research has examined the relationship between Islam (as one of the three monotheistic/Abrahamic religions), and environmental responsibility, the majority seek to only depict foundational principles (why) of this "theological" relationship through narrative research, citing evidence from authentic Islamic teachings, rather than empirical investigation informed by an analysis of primary sources of the Islamic religion (i.e. the sayings of God and/or the sayings/teachings of the Prophet Mohammed). This religious environmental movement has recently reached a new level by addressing questions of what (what is the environment, its regard, and the role humans toward it?), informed by empirical research. Abdelzaher and Abdelzaher (2015) have portrayed a high regard of the environment in Islam by explaining the underlying maxims of the Eco-Islam concept. Also, through a thorough content analysis of the holy Qur'an, Helfaya et al. (forthcoming) have explored components of the environment (i.e. human beings, water, air, land, plants, animals, and other natural resources) and the role of humans towards it (i.e. users, carers, or both). Although these studies provide a thorough foundation for explaining the whys and whats of Eco-Islam, they do less to inform us of the guiding application principles (hows) that individuals can directly refer to for specific action, as defined by the authentic evidence. 
This study, therefore, attempts to bridge this apparent gap in the Islamic environmental literature, and more specifically to extend the prior research on foundational principles (whys and whats) of the Eco-Islam concept (e.g. Abdelzaher and Abdelzaher 2015; Ansari et al. 2012; Helfaya et al. [forthcoming]; Hossain 2014; Naqvi 1997; Nasr 1967) into the question of how Islamic ethics can guide environmental actions of an individual, utilising an empirical evidence-based research approach rather than one adopting a solely spiritual perspective. For Muslims, the Qur'an is actually learned, practiced in daily life, recited regularly and very often memorised by practicing Muslims (not only scholars); it is expected to have a significant influence on the behaviour of Muslims when dealing with all components of the environment (Ali 2010). It is therefore a rich source for studying environmental ethics. With this in mind, this paper is primarily concerned with the question of: How can the Qur'anic verses guide us to the actual practice of Eco-Islam? And more specifically, which particular application principles can we draw to guide environmental policies?

This study seeks to contribute to the business ethics literature in three ways. First, it is one of the very early examinations of Islamic environmental ethics based on a qualitative analysis of the Qur'an. Second, the proposed framework is advancing the recently emerging empirical literature by extending it beyond the description of Eco-Islam foundational principles (whys and whats), and putting it into a practical context by combining the existing foundational understanding from the literature with the application principles (hows) needed to enhance individuals' environmental ethics. Finally, the paper proposes some specific business contexts where the applications of Eco-Islam principles, as revealed from our content analysis of the Qur'an, can be utilised.

The following section highlights the growing influence of Islamic ethics in the business context. Next, we discuss the origin, development, and foundational principles of Eco-Islam to underline the research gap and questions. This is followed by the research design. Then, the comprehensive Eco-Islam framework applications principles (hows) and their relevance in the marketplace and to other Abrahamic faiths are presented. The paper concludes with limitations and future research.

\section{Islam in the Business Context: A Growing Influence}

For centuries, religion has been a private matter, particularly among western societies, and therefore a "value-free society" developed (Rice 1999). In such a society, the focus was exclusively on the mechanics of economics informed by the economic rationality, which was 
unable to achieve the intended purposes on its own (Kamla 2015). Thus, over the past few decades there has been a growing realisation that value-free economics is a "misnomer" and there has been a crucial need for a moral dimension in conducting business (Rice 1999, p. 345). A holistic approach is necessary to transform economic life; emphasising and reflecting values other than financial and capitalistic (i.e. materialistic) for a betterment of society (Kamla 2015). To this end, religions have been seen as a powerful "complementary", rather than alternate, tool to combat irresponsible behaviours and attitudes, and transform economic life (e.g. Helfaya et al. [forthcoming]; Peace 2006; Uddin 2003). In this sense, among other faiths, the role and influence of the Islamic perspective on conducting business has grown exponentially over recent decades.

Muslims are governed by the Islamic religious law (known as Shari'ah), wherein Islamic ethics are embedded, which draws upon two primary sources accepted universally by all Muslims: the Qur'an (the word of God), and the Sunnah (the words and actions of the prophet Mohammed). While the Qur'an sets legislations, the Sunnah technically defines and clarifies these legislations with reference to the sayings (Qaul, Hadiths) of the Prophet Mohammed, His deed (Fi'l) and the act he confirmed (Iqrar). The Shari'ah regulates two major elements of an individual's life: God's worshipping (Ibadah) and relationships/transactions (Muamalah), aiming to protect faith (Din), human selves (Nafs), intellect (Aql), posterity (Nasl), and wealth (Maal) (Al-Ghazali 1901; Al-Juwayni 1979; Al-Najjar 2008; Dusuki and Abdullah 2007). Given this, Islam is arguably seen as "a universal set of values, applicable to every human being", at any time and place (Kersten 2011, p. 83), fundamentally emphasising concepts of the brotherhood/sisterhood and socio-economic justice with a balanced satisfaction of both the materialistic (earthly rewards) and spiritual needs (heavenly rewards) of all human beings (Chapra 1992; Rice 1999).

With this in mind, the Islamic perspective on conducting business has been substantially growing and gaining an influence within the worldwide business context. Currently, the so-called "Islamic economy" is emerging as a new paradigm, opposed to the "value-free economy" (Rice 1999), representing more than $\$ 8$ trillion in GDP, with a disposable income of $\$ 4.8$ billion and a relatively young population (62\% are under 30 years old). The global Islamic finance market has grown at $23 \%$ to over $\$ 1.2$ trillion in 2012 and is projected to reach $\$ 2.6$ trillion by 2017 (PWC 2013), representing Islamic banking (83\%), Islamic bonds (Sukuk) (12\%), Islamic funds (4\%), and Islamic insurance (Takaful) (1\%). According to the World Bank Islamic Banking Database, there are around 400 Islamic financial institutions licensed in 58 countries, offering Shari'ah compliant financial services/products. Additionally, a number of Islamic Shari'ah based indexes have also been launched, including: the Dow Jones Islamic Market Index in 1999, the Hang Seng Islamic China Index in 2007, the S\&P/TSX 60 Index in 2009, and the Islamic Bond Index on the 
London Stock Exchange. A number of countries (France, United Kingdom, South Korea, Japan, Honk Kong, and Australia) have made various fiscal and legal adjustments to meet the unique nature of Islamic finance products (i.e. taxation guidelines on Sukuk). To promote and support this emerging Islamic economy paradigm, a number of initiatives and organisations have been launched and established worldwide including: the World Islamic Economic Forum (WIEF) Foundation, the Global Islamic Economy Summit (GIES), the Accounting and Auditing Organisation for Islamic Financial Institutions (AAOIFI). Likewise, several annual conferences have been launched, a number of academic institutions have established research centres and designed graduate programmes (e.g. the Durham Centre for Islamic Economics and Finance, Rice University's Islamic Economics, and the Ali Vural Ak Centre for Global Islamic Studies at George Mason University). Also, numerous academic and professional articles, books, and new academic journals have been published.

Academic research has also witnessed a significant increase in studies focusing on Islamic ethics and business. In management, while Abuznaid (2006) emphasises the impact of major Islamic management principles upon managers' behaviour and perceptions, Abbasi et al. (2010) suggest an Islamic management model, where management leaders first submit their authorities to God's instructions (Qur'an) and then gain knowledge and practices from those instructions for a holistic approach to organisational management. Similarly, in a human resources management context, Hashim (2010) documents a significant positive relationship between human resources management practices informed by the Islamic values and the organisational commitment. Further, Abdelzaher et al. (2016, forthcoming) offer a multi-staged model based on Islamic values to enhance employee resilience and organisational survival during turbulent times. In marketing, Alserhan (2015) acknowledges in his book The Principles of Islamic Marketing, and Saeed et al. (2001) further identify the capabilities and strengths of the Islamic framework of international marketing ethics in creating and sustaining a strong ethical international marketing culture. More recently, following corporate scandals in the early 2000s, Abu-Tapanjeh (2009) compares the nature and applications of Islamic principles of corporate governance with conventional principles of corporate governance, with special reference to the Organisation of Economic Co-operation and Development (OECD). In accounting, the relationship between Islam and accounting focuses on Zakat accounting (Islamic charity) (e.g. Haniffa 2001), accounting in interest-free economies (e.g. Dusuki and Abdullah 2007), accounting regulations in countries substantively influenced by the Islamic law (e.g. Faruqi 2007), and Islamic social accounting (e.g. Kamla et al. 2006). 
Based on the above, it can be claimed that the relationship between Islamic ethics and business has progressed a great deal during the last three decades at least, thus making the discussion of Islamic environmental ethics timely and relevant. The next section sheds light on the definition of, and development of, the Islamic environmental responsibility notion (labelled by the term "Eco-Islam") and further discusses the foundational Islamic philosophical principles (whys and whats) supporting the Eco-Islam concept.

\section{Literature Review: Islam and the Natural World}

\section{Definition and Development of Eco-Islam}

Corporate environmentalism has been in place for several decades. ${ }^{2}$ However, various environmental problems are still prevailing, if not escalating (Babcock 2009; Campbell 2006; Gray et al. 1995; Hsieh 2004; Kula 2001). This has led Helfaya et al. (forthcoming) to argue that "such corporate environmental approaches have been less sufficient in changing attitudes that constitute the environmentally damaging consequences of society"; thus a need for a complementary approach has arisen, with special reference to religion. Given the powerful and persuasive role that religion can play on the values, attitudes, and behaviour of individuals, in recent years the term "Eco-Islam" has become the label used to define the Islamic ecological ethics that interpret the Qur'an and the body of Hadiths in a contemporary ecological way of life, as an inherent Muslim necessity/obligation (Zbidi 2013).

According to Schwencke (2012) and Zbidi (2013), the Eco-Islam movement started in the 1960s as a response to the controversial beliefs of the historian Lynn White Junior, who viewed the monotheistic religions as the root of the ecological crisis. Seyyed Hossein Nasr, believed to be the founding father of this early Islamic environmentalism movement, wrote his book, Man and Nature: The Spiritual Crises of Modern Man (1967), explaining that religions may provide humanity with the keys to the way out of the crises. Rather than blaming the monotheistic religions, Nasr calls for a rediscovery of, and reconnection with, heritages of the powerful religious teachings concerning the (scarce) natural world that have been lost with advent of modernity (i.e. value-free society). Since, Eco-Islam has become a growing subject area of conceptual and empirical research, focusing on environmental protection in Islam, the impact of spirituality on corporate social responsibility, Islamic principles' content for the environment, and the concept of corporate social responsibility in a wider cultural and religious setting (e.g.

\footnotetext{
2 "The organization-wide recognition of the legitimacy and importance of the biophysical environment in the formulation of organization strategy, and the integration of environmental issues into the strategic planning process." (Banerjee 2002, p. 181)
} 
Bagader et al. 1994; Bubna-Litic 2009; Dusuki 2008; Jusoff and Abu Samah 2011; Kamla et al. 2006; Khan and Karim 2010; Kula 2001; Ozdemir 2003; Roughton 2007; Salem et al. 2012; Zinkin 2007).

\section{Foundation Principles of Eco-Islam - The Whys}

According to Islamic teachings, the environment is a gift donated to humankind by God. Both individuals and societies, therefore, are duty-bound to protect and promote its natural resources, including air, the climate, water, seas, flora and fauna, etc., and refrain from any act likely to cause pollution or damage to the eco-system or disturb the balance (Ansari et al. 2012; Hasan 2006; Hossain 2014; ISESCO 2002, Article 3). The underlying logic of the relationship between God, humans, and the environment is founded on the belief that God created the whole universe and made it subject to humankind - but not simply for the latter to exploit it for their material benefit. Rather, humankind's ultimate goal on the earth is to worship God (not just by performing religious duties such as prayers), therefore, all their interactions with the universe are subject to God's laws (but also by sustainably developing the earth) (Ansari and Jamal 20012002; Khalid 2002; Naqvi 1997).

Indeed, the relationship between God, humankind, and the environment is inspired by three foundational (whys) Islamic principles, revealed in the Qur'an and the authenticated sayings/actions of the prophet Mohammed, and examined in prior research (e.g. Naqvi 1981; Kamla et al. 2006). These principles form the underlying logic (whys) of humankind's (normative) behavioural actions towards the environment: (i) unity of all creatures under the one God (Tawheed), (ii) humankind's role as vice-regency (Khalifa), and (iii) humankind's pursuit of public good (Maslahah). These three principles are discussed as follows.

\section{All Creatures are Under the One God: Tawheed}

According to Ansari et al. (2012), Hossain (2014), Khalid (2002), Kamla et al. (2006), and Naqvi $(1981,1997)$, the source of all Islamic environmental ethics comes from the belief in the unity of one God (Tawheed). The Tawheed principle creates a link between the infinite and perfect being and the finite and imperfect world (Naqvi 1981). It also reflects humankind's continuous relationship with God and His creations. By uniting humankind's social, environmental, political, and economic aspects, their lives become stable and safe, which leads to a universal green brotherhood (Abdelzaher and Abdelzaher 2015; Hasan 2006; Islam 2012; Naqvi 1997). The all-powerfulness of God results in a social role of unity. He is all-powerful and all-knowing: “... Allah is Able to do all things" (Qur'an 35:1); “... He is the Knower, the Mighty” (Qur'an 
30:54). It also reflects an environmental role of unity; all things belong to God: “... Allah's is the heritage of the heavens and the earth, and Allah is Informed of what ye do" (Qur'an 3:180; see also Qur'an 4:126). Accordingly, God in Islam is believed to be the source and owner of all earthly creations; also, all creations are interconnected through their submission to God, fulfilling their divine purpose (Naqvi 1981; 1997; Ozdemir 2003; Roughton 2007; Yasmin et al. 2014). This concept implies both the oneness (monotheism) of God and the equality (equilibrium) of all God's creations in the worship of God, and "their equality as partners in terms of the due respectful recognition of the existence of all and the due appreciation of interdependency and interconnectedness between all” (p. 249) (see also, Naqvi 1997; Naseef 1998; Yasmin et al. 2014).

From an environmental perspective, the "unity of God" is interpreted as God creating humankind within the pattern of the natural world, in the state of being able to distinguish between good, bad, and neither good nor bad (Naqvi 1997, 2003). Thus, God expects humans to make ethical choices for their lives. Further, Naqvi (1981) argues that the concept of social equilibrium (Aladl and Al-ihsan) relates to unity of God and is an integral principle of the Tawheed (Kamla et al. 2006; Naqvi 1981, 1997); "Lo! Allah enjoineth justice and kindness ...” (Qur'an 16:90). While equilibrium represents a social idea of the virtues of legal, political, and economic organisations, kindness or beneficence (Ihasan), and justice (Adl), are integral principles of the Tawheed (Kamla et al. 2006; Naqvi 1981, 1997). Al-Qaradawi (2000), a prominent Islamic scholar, states that Muslims must be "sincere to the truth and justice, and ethical ... to God's creations", referring to the prohibition of abuse and the respect for the natural world including the human being among other creations (Al-Qaradawi, 2000, cited in Kamla et al. 2006, p. 250). From an environmental perspective, both social equilibrium and Tawheed should lead to socioeconomic justice, meaning that each human should receive what they deserve from the natural world, as well as participating positively in maintaining a high quality of life for others (Hossain 2014; Naqvi 1981, 2003; Platonova 2013).

\section{Human Role of Vice-Regency: Khalifa}

Following the Tawheed principle, Islam envisages human beings as part of the natural world (Helfaya et al., forthcoming) and that God intends for them to make ethical choices in response to what they encounter on the earth (Bekun 1996; Chapra 1979; Naqvi 1997; Yasmin et al. 2014). From an Islamic perspective, the human is merely a guardian of the environment and its components; Islam strongly promotes the intergenerational justice and sustainable development (Ansari and Jamal 2001-2002; Chapra 1979; Islam 2012). This gives the human a special 
position in this relationship with God and the environment as a vicegerent, steward, representative, and/or agent (Khalifa) of God on the earth (Lewis 2001): "Lo! I am about to place a viceroy on earth" (Qur'an 2:30); “... Verily! We have placed you as a successor on earth...” (Qur'an 38:26).

Although the vice-regency principle gives the human being the highest authority on earth, it does not mean a privilege has been bestowed to abuse the earth for material benefit (Ansari et al. 2012; Hasan 2006; Hossain 2014; Kamla et al. 2006; Naqvi 1981, 2003). Rather, humankind is expected to practice authority in ways that serve God's will, by looking after and governing the self and other creations (Abdel-Haleem 1998). In many verses of the Qur'an, God warns human beings (Muslims and non-Muslims) that wastage of natural resource is a sin and destroying the balance of the earth (See Qur'an 7:31 and 17:26-27). Prophet Mohammed was quoted as saying "Do not pluck even the leaves of plants without any useful purpose...", and "He who cuts a lottree without justification, God will send him to Hellfire". Prophet Mohammed prohibited Muslims from wasting water while performing their ablution for prayers, even if at the riverbank. In this regard, Al-Qaradawi (2000) explains that fulfilling the Khalifa's role requires human beings to spread justice, truth, good deeds, virtue, and modesty to all of God's creations, living and non-living.

According to Naqvi (1981, 1997), the "theomorphic role" of humankind as God's vicegerent (Khalifa) on earth has two elements: free will (Ikhtiyar) and responsibility (Fard). Free will (Ikhtiyar) is an element that each human being has, and gives him/her the ability to make choices in situations where there may be conflict of interests or opposing matters involved (Beekun 1996; Chapra 1979; Naqvi 2003; Yasmin et al. 2014). Humankind's free will is unrestricted and voluntary, so it is possible to make wrong decisions. However, it is in a person's best interests to make the right decision: "Say: O mankind! Now hath the Truth from your Lord come unto you. So whosoever is guided, is guided only for (the good of) his soul, and whosoever erreth erreth only against it. And I am not a warder over you” (Qur'an 10:108; see also, Qur'an 13:11). Responsibility (Fard) has two wings (Chapra 1979; Naqvi 2003). The first is the person's trustee status on earth, while the second is the voluntaristic aspect. The human being should attempt to appreciate the position of being God's Khalifa on earth and the use of its resources (Beekun 1996). Undoubtedly, this encompasses actions that enhance the welfare of the least-privileged in the community (see, Qur'an 3:92; Naqvi 2003). In practice, a human being maintains their free will from greed by exercising their responsibility; otherwise they deny their faith (Qur'an 107:13). From a legal perspective, Roughton (2007) refers to the human's rights on earth as "usufructuary", where "usufruct" means the right of temporary possession and enjoyment of 
something (e.g. the environment) that belongs to somebody else (e.g. God) by someone (e.g. humankind), without causing damage or changing its substance. However, within the context of Islamic usufruct, Muslims are not only acting as users or protectors of the earth, but also as prosperity (i.e. cultivating it to the highest point consistent with sustainability) of the earth for coming generations (Kamla et al. 2006, p. 251; see also Beekun 1996; Chapra 1979).

\section{Pursuit of The Public Good: Maslahah}

According to the former two principles of Tawheed and Khalifa, the decision to use natural resources is a responsible choice (Jalil 2006; Kamali 1989). In Islam, natural resources are entrusted by God, and His vicegerent is commanded to use these resources in the right way within the Shari'ah law (Ansari and Jamal 2001-2002; Haneef 1997; Kamali 1989). Accordingly, the prioritisation of actions to use these resources is embedded in the Islamic jurisprudence, by conveying different rewards/values of actions, namely: obligatory (Wajib), recommended (Mandub), permissible (Mubah), reprehensible (Makruh), and forbidden (Hram) (Al-Ghazali 1998). These values aim to secure benefits for people and/or protect them against any degree of corruption and evil (Dusuki and Abdullah 2007; Haniffa 2001; Jalil 2006).

In particular, the concept of public good (Maslahah) aims at the sustainable achievement of good, welfare, advantages, and benefits for creatures (Jalil 2006) alongside prohibition of any evil and corruption, as expressed in many verses of the Qur'an with the words "commanding good" (e.g. Qur'an 2:177; 3:113-115) and “prohibiting evil/corruption” (e.g. Qur'an 7:56; 2:205). Al-Gazali (1998, cited in Jalil 2006, p. 3) defines public good (Maslahah) as "the preservation of the religion, life, mind, offspring and wealth" (known as Maqasid al-Shari'ah). He concludes that everything leading to the preservation of these five foundations is Maslahah, and its removal is corruption or "Mafsadah" (Al-Gazali 1998, cited in Ibrahim 2000).

This principle switches concerns from people to community (Muslims and non-Muslims) (Kamla et al. 2006), thus meaning that the State has the right, when there is a case of need, to intervene for the sake of public interest and welfare. At the time of the Prophet Mohammed and His Caliphs, for example, land (called hima land) can be preserved for the purposes of the public utility (e.g. animal grazing, rehabilitation of degraded land, protection of biodiversity, wetland, etc.) in the case of a need arising (Dutton 1992). A more recent example of this emerged when the Saudi government intervened and gave $\$ 35.5$ billion to the owners of properties around the Grand Mosque in Mekkah to make an urgently needed expansion and modernisation for the public utility, serving and accommodating over 6 million pilgrims every year (Helfaya et al., forthcoming). 
In the interest of the public good, the Prophet Mohammed was quoted as saying "avoiding harm is paramount to achieving utility", "no harm shall be inflicted or reciprocated in Islam", "no harm and no harming", and "every Muslim who plants a tree will be rewarded in the hereafter for every animal or for every human who eats of this tree". In Islam, private property is a legitimate form of ownership, but this ownership should be used as a way of achieving public good. For example, "dead" land will belong to anybody who is able to recover it and bring it back to productivity, in recognition of the investment and risk taken.

In the context of business, the "public good" principle does not suggest that Islam opposes making a profit. Rather, it means that businesses should not be driven solely by profit maximisation, but by the "pursuit of ultimate happiness in this life and in the Hereafter" (Dusuki and Abdullah 2007). In Islam, under the theological contract, it is the responsibility of each member in the community, as a Khalifa, to promote social welfare and prevent harm to the natural world. This Islamic sense of duty and spirit of sacrifice "helps remove self-centeredness and covetousness and promotes compassion, caring, cooperation, and harmony among people within the natural world" (Dusuki and Abdullah 2007, p. 34; see also Kamali 1989). The Qur'anic verses (68:17-32) have stressed this sense of duty and spirit working for the public good by narrating the story of the people of the garden. These were brothers who inherited a garden from their late father, who gave much of its fruits to charity. But the brothers failed to act in the same way as their late father and intended to deprive the poor of its fruits, thus God punished them.

\section{Foundation Principles of Eco-Islam - Moving from Why to What}

Drawing upon the aforementioned prior research on the foundational principles that guide the belief of why humankind, according to Islamic teachings, should care about the environment, some recent scholarly work has attempted to advance this conceptual foundation by moving from the why questions and addressing the what questions, namely: What is the meaning/regard of the environment in the Qur'an?; What is the extent to which environmental reasonability is reflected in the Qur'an?; and What types of environmental elements are contained in the Qur'an?

Abdelzaher and Abdelzaher (2015) further develop the concept of Eco-Islam by describing eight underlying maxims about what the meaning/regard of the environment is in the Qur'an. The first five environmental maxims reflect the concept of environment "as a creation of God, sustained and protected by God, is a sign of God to human beings, is itself in a state of worship of God, and is a witness for/against human actions" (Abdelzaher and Abdelzaher 2015). These first five 
maxims present the perceived concept/high regard of the environment as described by Islamic teachings, thus specifically extending the beliefs behind the relationship between humans and the environment (i.e. the foundational whys). However, they do not offer guidance on the behaviour principles of how this high regard of the environment can be translated into actions.

More recently, informed by a thorough content analysis of the Qur'an, Helfaya et al.'s (forthcoming) analysis has revealed that 675 verses in 84 chapters, throughout the 30 parts of the Qur'an, have environmental content relating to the core components of the environments: human beings, water, air, land, plant, animals, and other natural resources. They also explain that this environmental content is established on, and informed by, the belief that "humans are vicegerents [user and carer of such environmental resources] of God on the earth and are vicegerents of God on the earth and their behaviours and actions are motivated by earthly and heavenly rewards".

Although Abdelzaher and Abdelzaher (2015) and Helfaya et al. (forthcoming) have further advanced the existing Islamic environmental ethics literature, their focus is still on enhancing the beliefs (whys and whats) about the environment than guiding towards behavioural actions.

\section{The Missing Step Forward: From Beliefs (Why and What) to Behaviours (How)}

Figure 1 summarises the existing literature on the relationship between Islam and environmental ethics. While prior research defined the three foundational Islamic ethical principles (whys), and further extended them to the specific beliefs about the meaning/regard of the environment, its components, and the role of the human being towards it (whats), it is essential to explore how such beliefs could guide an individual's environmental behavioural actions.

Our study methodologically and conceptually advances prior Eco-Islam research by suggesting empirically informed principles to put the Eco-Islam concept into action. Specifically, our empirical investigation addresses two questions: (i) How can we take our belief of "Eco-Islam" to actually guide behaviours and outcomes? And (ii) In which business contexts are these behavioural principles more immediately applicable? By addressing these two questions, this study attempts to make a further transition from belief and understanding of God's teachings about the environment to a series of action principles needed to protect His creatures (Chapra 1979; Islam 2012; Naqvi 2003). The logic behind our identified gap is based on the notion that the individual's beliefs about God's teachings will usually guide them to behave in accordance with this belief. Therefore, studying the how component of the Eco-Islam concept will add to our ability to leverage such beliefs in the marketplace. 


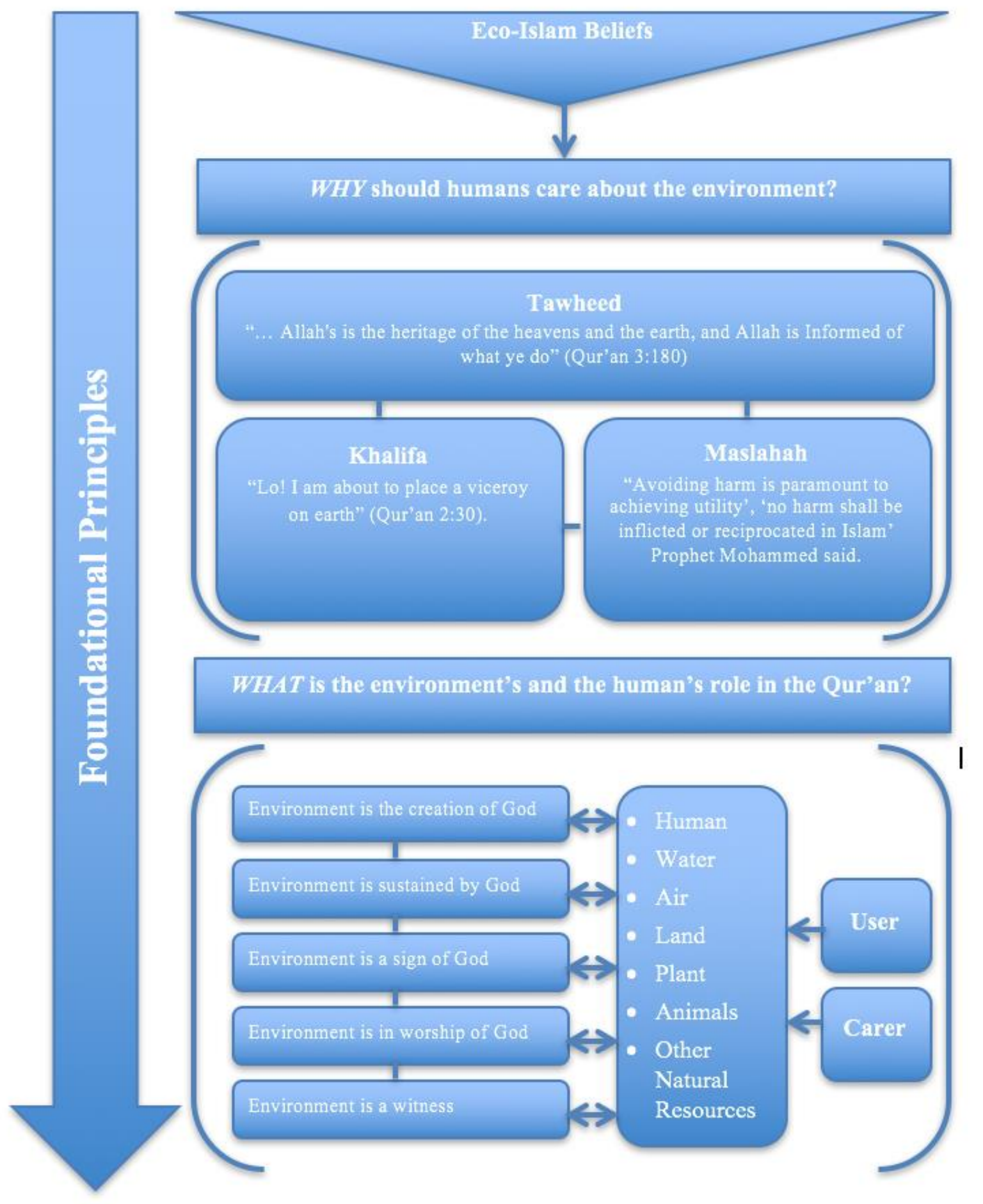

Figure 1: Eco-Islam Beliefs 


\section{Research Design}

Given the nature of the study (i.e. relatively understudied and explorative) and to achieve the research questions, we followed an exploratory qualitative approach (Braun and Clarke 2006). Content analysis involves "any technique for making inferences by objectively and systematically identifying specified characteristics of messages" (Holsti 1969, p. 14). According to Smith and Taffler (2000) and Krippendorf (2004), two distinct approaches of content analysis are usually applied: the form-oriented (quantitative) approach and the meaning-oriented (qualitative) approach. While the quantitative form is based on counting words/sentences/pages, yielding reliable results, the qualitative form is mainly based on investigating the underlying themes of the messages being analysed rather than summarising data into percentages, which often reduce the richness of the data. In this study, we use meaning-oriented/thematic content analysis to extend the recent empirical work of Helfaya et al. (forthcoming), aiming to find trends and patterns in the data through a recursive process (Braun and Clarke 2006).

For Muslims, the Qur'an is the divine message of God revealed to all humanity by the prophet Mohammed. It is believed to be a constitution for Muslims' daily life, it is, therefore, expected to have a significant influence on behaviours of Muslims in their interaction with all components of the environment (Ali 2010). Because of that, we thoroughly examined the verses in the Qur'an as a significant literary source for individuals' environmental ethics (Helfaya et al., forthcoming).

The key question driving our analysis of the Qur'anic verses focused on revealing the application principles that can guide human behavioural action towards the environment. We first gathered all verses that contained references to the natural environment by examining the whole text of the Qur'an (6,236 verses, categorised in 114 chapters in 30 roughly equal parts). As a result, a database of all Qur'anic verses with reference to human interaction with the environment was created. For the identification of relevant verses, an authenticated interpretation of the Qur'an (Al-Sabouny 1978) was chosen. As believed by the majority of Muslims, there is no a singular official interpretation for the Qur'an. Given the richness of the Qur'anic text, its language often tends to be symbolic, carrying various social and cultural meanings that can result in a difference across various schools of thoughts and socio-cultural backgrounds (Islamic Research Foundation International, http://www.irfi.org). Thus, interpretations of the Qur'an can arguably be seen as synonyms, rather than antonyms, of the same text (Helfaya et al., forthcoming). We adopted AlSabouny's 1978 Qur'anic interpretation for a number of reasons, as justified by Helfaya et al. (forthcoming): (i) it is written by a key scholar of Qur'anic interpretations in recent times, (ii) he was chosen by the Dubai International Holy Qur'an Award as the Islamic Character of 2007 for 
his publications, with special reference to the Qur'an interpretation, (iii) the interpretation is written in plain Arabic language, so easy to understand by non-experts, (iv) the interpretation is informed by, and based on, other highly authenticated interpretations of prominent scholars in this area of Islamic studies, such as Al-Tabari and Ibn Kathir, and (v) for every single verse, the author of this interpretation discusses meanings, context, and reasons for revelations, which helped in identifying and verifying relevant verses.

Primarily, a careful reading of the entire Arabic version of the holy Qur'an, alongside the chosen authenticated interpretation, was conducted independently by two authors (both are of Muslim faith and Arabic native speakers). The two sets of data/verses were collected in order to measure inter-rater reliability using percentage of agreement (Cuomo et al. 2016; Dewey 1983). A high overlap was found as the percentage of agreement was approximately 95\%, which is above the appropriate minimum level of reliability (Dewey 1983). The two authors/coders met to discuss the differences $(<5 \%)$, which have been clarified and agreed with supporting evidence from the relevant literature and other authenticated Qur'anic interpretations, resulting in a list of all Qur'anic verses (i.e. 675) that make a reference to the environment and/or the responsibility of humankind towards it.

The next stage of the content analysis was inductive interpretative analysis, which is a datadriven approach to highlight the emerging themes within the Qur'anic verses (Leitch et al. 2009). This was done with the aim of extracting key themes in response to the research question. It is important to note that "the 'keyness' of a theme is not necessarily dependent on quantifiable measures", but rather on whether "it captures something important in relation to the overall research question" (Braun and Clarke 2006, p. 82). Each verse was then carefully read numerous times. We followed the five-stage approach recommended by Braun and Clarke (2006, p. 15-23) for thematic analysis, which involved “(1) Familiarising yourself with your data... (2) Generating initial codes... (3) Searching for themes... (4) Reviewing themes... (5) Defining and naming themes: Ongoing analysis to refine the specifics of each theme, and the overall story the analysis tells, generating clear definitions and names for each theme. (6). Producing the report".

The process revealed four themes constituting the proposed application principles (how) of EcoIslam: (i) seek balance; maintain equilibrium, (ii) avoid overconsumption; apply moderation, (iii) practice self-accountability; preserve justice, and (iv) acknowledge interdependence; observe modesty. These four application principles are to be discussed in the next section and illustrated in Figure 2. 


\section{Eco-Islam Framework Application Principles - The Hows}

\section{Principle 1: Seek Balance - Maintain Equilibrium (Qadr)}

One of the main revealed themes revolves around the concept of seeking balance and maintaining equilibrium (defined as "Qadr" in the Qur'an). This concept is communicated several times in the Qur'an in different contexts, with the underlying message that Allah has created everything in this world with a sense of balance/proportion. It is the responsibility of human beings (as God's Khalifa on earth) to preserve this natural order or balance between all creations; this is achieved when humans do not alter or damage any of God's creations, which includes humans, water, air, land, plants, animals, and other natural resources. Corruptions on earth in the form of pollution, overconsumption, and wastefulness are all factors that can distort this balance. "Harm is simply a disruption of the created balance" (Abdelzaher and Abdelzaher 2015, p. 10). In this context, the Qur'an states that:

Verily We have already sent Our messengers with clear evidences and sent down with them the Scripture and the balance that the people may maintain [their affairs] in justice ...

(Qur'an 57:25)

It is mentioned specifically in the Qur'an that Allah is the source of this balance and He has created everything within this sense: "Lo! We have created everything by measure" (Qur'an 54:49). Earth's creations are a function of specific predetermined proportions and ratios, which maintain its livelihood. It is not a random process, but one which requires calculated measures and ratios that must be maintained and unaltered to maintain a sustainable life.

And We have stretched the earth and put therein anchors, and caused to grow therein everything proportionately.

(Qur'an 15:19)

And We made the earth flow with springs, so the two waters met to such a quantity, which was already decreed.

(Qur'an 54:12)

Al-Qaradawi (2000) argues that failure to watch God's measure, or to maintain God's balance, is expected to lead to damaging consequences for the environment, such as disturbing the ecobalance or exhausting the earth's resources. This suggests that humankind's relationship with God and His creations should be one of "sustainable utilisation"; "lives according to God's will while conserving natural resources and preventing degradation of the natural world created by God" (Roughton 2007, p. 105). God established a measured and balanced universe and creations 
that human beings must benefit from and not disturb at any level, "whether at that of the harmony of nature or in the spheres of human justice, morality or everyday commerce ... the principle of balance, measure and moderation is all-pervasive ...” (Hobson 1998, p. 41; Roughton 2007).

The principle of balance is very much relevant to today's environmental dialogue. Sustainability development goals call for the use of resources in ways that do not jeopardise the future use of next generations; one of the most effective ways of doing this is to maintain the natural balance. Wills (2013) puts forth the argument for "green equilibrium" to highlight the important of striking the balance between natural resources and human demands. Traditionally, human interventions have been found to alter or offset the natural balance of resources. A state of nonequilibrium may be driven by the overconsumption, misuse, or in the case of GMOs scientifically intervening to alter natural resources. Eden and Bear (2011) studied how anglers' model for the preservation of natural equilibrium (particularly water resources), but natural, occurring ecological disturbances can also result in a state of imbalance that can further challenge sustainability goals (Mori 2011). Human consciousness in maintaining the ecological equilibrium can help shape how they behave towards the environment and its components.

\section{Principle 2: Avoid Overconsumption (Israf/Tabzeer) - Apply Moderation (Wasateya)}

Another main theme emerging from our analysis was particular to the concept of conscious moderation (Wasataya in Arabic) in the use of resources. The Qur'an states the importance of not overspending (Israf), or indulging in careless overconsumption (Tabzeer), stressing the importance of managing the resources given to us on earth (Al-Sabouny 1978). The Qur'an has made a clear distinction between extravagance (Israf) and wastage (Tabzeer). Extravagance is defined as over-expenditure in areas where spending is permissible (eating, drinking, etc.): “eat and drink but waste not by extravagance" (Qur'an 7:31). Wastage or Tabzeer is committed when indulgence occurs where spending is impermissible. Allah states in the Qur'an that He frowns upon those who waste (Tabzeer): "Verily the squanderers are ever the brethren of the Satans..." (Qur'an 17:27).

Further, the Qur'an calls for the use of resources in moderation, which means neither overconsumption nor frugality:

And let not thy hand be chained to thy neck nor open it with a complete opening, lest thou sit down rebuked, denuded.

(Qur'an 17:29) 
And those who when they expend neither exceed the limit nor they are straitened and remain in between the two on the middle path.

(Qur'an 25:67).

The verses about the Prophet Joseph in the Qur'an (Chapter 12) highlight the similar message behind moderate consumption and management of agriculture resources, which prolonged their use and helped the people of Egypt not only to sustain their livelihood against starvation, but also to maintain economic authority over neighbouring nations. Allah also states that having resources in excess of need is detrimental for humans, leading them to waste more and commit injustice. The Qur'an states:

And had Allah expanded the provisions of all His bondmen, they would have necessarily then spread mischief in the earth, but He sends down according to a measure as He pleases, undoubtedly, He is Aware of His bondmen, Sees them.

(Qur'an 42:27)

The concept of preservation of resources and avoiding overconsumption are fundamental to the sustainability dialogue. Unless individuals learn to eliminate extravagance/waste and prolong the useful life of existing resources, future generations are heading for a catastrophe (Porter and Reinhardt 2007). The essence of the pursuit of a closed loop economy and "cradle to cradle" is the design of products to eliminate their waste and prolong useful life. However, despite the increased federal and organisational-level regulations in waste management, unless individuals are committed to the logic, or preferably ethics, of minimising waste, it is unlikely to make a difference. For example, the members of organisations are less likely to waste when they believe it to be unethical, than when there is a company policy that tells them not to do so. Whether the resource is natural, financial, or personnel-related, studies have shown that top management who are committed to the concepts of resource conservation are more likely to build strong organisations (Barney and Hesterly 2008).

\section{Principle 3: Practice Self-Accountability (Muhasaba) - Preserve Justice (Adl)}

The concept of being accountable (Muhasaba) for all actions on earth and in the hereafter to a higher being is strongly emphasised in the Qur'anic verses. This is particularly interesting when applied to the environment, as very often injustices towards the environment occur unnoticed by worldly mechanisms, leaving some individual actions unpunished. Allah stresses that humans will be judged accordingly for any and all acts on earth, which includes any injustices, wastefulness, and overconsumption beyond their needs in numerous verses (e.g. Qur'an 3:30; 17:13-14). Humans are accountable before Allah for how they dealt with Allah's blessings and 
creations, including food, animals, water, etc., and will either receive rewards or punishments for their actions. Abdelzaher and Abdelzaher (2015) argue that "whether the source of this accountability is the self, the actual environment as a witness, or The Creator himself, being rewarded or punished for actions is unquestionable" (p. 14). Allah states in the Qur'an that no human action goes unaccounted:

And whoso doeth good an atom's weight will see it then. And whoso doeth ill an atom's weight will see it then.

(Qur'an 99:7-8)

And say (unto them): Act! Allah will behold your actions, and (so will) His messenger and the believers, and ye will be brought back to the Knower of the Invisible and the Visible, and He will tell you what ye used to do.

(Qur'an 9:105)

In fact, all of God's blessings on this earth are created and made subject for the human being to enjoy but s/he will be asked: "Then, undoubtedly, you shall surely be asked about the favours" (Qur'an 102:8). Allah also states that our purpose on this earth is to undergo His test: "Undoubtedly We adorned the earth whatever is on it, so that We may test them as to which of them is best in works" (Qur'an 18:7). The emphasis on accountability manifests in humans acting in a manner that preserve justice on earth for all creations. The prophetic teachings also support this principle of accountability for actions towards environmental creations. In the famous story of the crying camel, Prophet Mohammad condemned the mistreatment and overworking of animals (i.e. one of God's creatures), and reminded the camel's owner that he should take great care of the camel in return for its hard work.

Such accountability is not limited to any time or stage in one's life, but humans are accountable as long as they are on earth. This is highlighted in the hadith that: "If the Hour (the day of Resurrection) is about to be established and one of you was holding a palm shoot, let him take advantage of even one second before the Hour is established to plant it" - Al-Albani. The emphasis is to consider the principle of accountability, even in your last moments on earth.

The concept of accountability is well documented in the environmental management and sustainability literature. At a micro level, organisations must be held accountable for their actions and internalise the costs of their polluting actions, instead of attempting to externalising this and making society pay in the form of increased pollution/toxic related health issues, population migration, and severe weather conditions. Trucost is an organisation that seeks to help companies become more accountable by putting a financial cost on their ecological footprint as well as on the environmental impact of their value chain (Trucost 2010). Companies can track 
and monitor their ecological footprint and hold specific units responsible for their actions. Shareholders and NGOs play an instrumental role in guiding organisations' environmental reporting, which is key to establishing accountability and justice in the marketplace. At a more macro, country level, the dialogue on holding nations accountable for their carbon productions is well established (Ekardt 2009). The goal of the Climate Change Summit in Paris, which gathered nations from all the over the world, centres on the concept of environmental justice in the context of consequences of climate change. The underlying case for accountability is that developed countries have higher ecological footprints, while developing countries are the most severely hit by the consequences (Abdelzaher et al. 2016, forthcoming). This drove nations to actually agree on a specific dollar amount for developed countries to pay to the developing world as support funds to help them deal with the consequences of climate change, hence attempting to establish accountability of actions and justice at a country level.

It is worth stating that much of these pro-accountability initiatives and agreements are voluntary and nonbinding, which puts the burden of ensuring compliance less with the regulators and more into the environmental ethics of the individual.

\section{Principle \#4: Acknowledge Interdependence - Observe Modesty (Tawadu)}

The final key theme that has emerged from our analysis can be referred to as "Tawadu". While the above foundational principles discussed the notion of vice-regency and human stewardship on earth, this requires a state of modesty and servitude. Below, we discuss evidence to support this notion of (1) observing modesty (Tawadu) in action towards all creations, and (2) acknowledging humankind's commonalities and interdependence with other creations.

God, as the source of all creations, has created, and made subject for the human the whole of nature with all its components to enjoy. This is an honour of itself; s/he must not think that s/he is above other creations in an "arrogant" manner.

The Qur'an verses warn against arrogance and praises those who walk on earth in a modest manner and realise they are one among God's many creations:

And walk not in the earth exultant. Lo! thou canst not rend the earth, nor canst thou stretch to the height of the hills.

(Qur'an 17:37)

And the bondmen of the Most Affectionate are those who walk on the earth modestly and when the ignorant address them, they say, "peace".

(Qur'an 25:63) 
Allah reminds humans of their initial creation; they must remember their roots possess a sense of humility:

Hath there come upon man (ever) any period of time in which he was a thing unremembered? (1) We create man from a drop of thickened fluid to test him; so We make him hearing, knowing. (2) We have shown him the way, whether he be grateful or ungrateful.

(Qur'an 76:1-2)

Furthermore, the prophet hadith states "He who has in his heart as much faith as a grain of mustard seed will not enter hell, and he who has in his heart as much pride as a grain of mustard seed will not enter paradise" - Sunan Ibn Majah.

A core part of exercising modesty is to acknowledge and protect the evident interdependence that exists between creations. Allah makes the comparison between humans and other creations to highlight the sense of similarity, sharing of a common life on earth, a common worship to the One God, and the evident natural interdependence:

There is not an animal in the earth, nor a flying creature flying on two wings, but they are peoples like unto you. We have neglected nothing in the Book of Our decrees. Then unto their Lord they will be gathered.

(Qur'an 3:38)

A hadith of the prophet is narrated that when he saw the moon acknowledge they both worshipped the same God: "O Allah, bring it over us with blessing and faith, and security and Islam. My Lord and your Lord is Allah" (https://sunnah.com/tirmidhi/48/82).

In the Qur'an, it is stated that all creations are in a state of worship of God. This implies that no creation is to be harmed because it is in a state of worship to its Creator. Allah states:

Have you not seen that all who are in the heavens and the glorify Allah and so do the birds spreading their wings? Everyone knows his prayer and his way of glorifying. And Allah knows their deeds. And it is for Allah only the Kingdom of heavens and earth and to Allah is the return.

(Qur'an 24:41-42).

The seven heavens and the earth and all that is therein, glorify Him and there is not a thing but glorifies His Praise. But you understand not their glorification. Truly, He is Ever Forbearing, Oft-Forgiving.

(Qur'an, 17:44)

The earth blessings are to be shared by both animal and humans. As mentioned in the Qur'an:

The example of worldly life is just like the water We sent down from the sky, then the vegetation of the earth grew with it, which is (meant to be) eaten by men and cattle... 
In many chapters of the Qur'an, Allah honours several types of animals and insects in stories, acknowledging we should respect and learn from other creations' way of life, hence a sense of interdependence between human beings and God's other creations (i.e. natural resources). For example, Allah points us to the value of bees to humans as a source of medicine, when He states:

And your Lord inspired the bee that makes houses in the hills and in the trees and in the roofs. Then eat of every kind of fruit, and walk the ways of your Lord that is smooth and easy for you. There comes out from their bellies a drink of varied colors in which there is healing for the people Undoubtedly in it there assign for those who ponder.

(Qur'an 16:68)

The companions of Prophet Mohammed have greatly valued modesty in making use of environmental resources. For example, Abu Baker, the first Muslim Caliph, had a great concern for protecting the environment and its resources (Khalid 2002), instructing Muslim soldiers not to harm women, children, and animals, destroy crops, or cut down trees. This implicitly underlines the core value of protecting rights of plants and animals, even on enemy grounds (Abdelzaher and Abdelzaher 2015; Ansari and Jamal 2001-2002; Beekun 1996; Khalid 2002, 2008).

Furthermore, Allah explains how different environmental components (wind, rain, clouds, plants etc.) serve different functions on earth to benefit humanity. Interestingly, He also states that all creations serve assigned roles by Allah on Earth, further enforcing the notion that they should not be disrupted:

Have you not seen how God makes the clouds move gently, then joins them together, then makes them into a stack, and then you see the rain come out of It ...

(Qur'an 24:43)

And We have placed on the earth firm mountains, lest it should shake with them, and We placed therein broad highways for them to pass through, that they may be guided.

(Qur'an 21:31)

And the mountains as pegs.

(Qur'an 78:7)

And We send the winds fertilizing (to fill heavily the clouds with water), then caused the water (rain) to descend from the sky, and We gave it to you to drink, and it is not you who are the owners of its stores [i.e. to give water to whom you like or to withhold it from whom you like].

(Qur'an 15:22) 
In summary, treating Allah's creations with respect, avoiding human arrogance, and acknowledging our dependence on their livelihood is required by Islamic teachings.

The concept of interdependence is well documented in the sustainability dialogue, which calls for sustaining and respecting the evident interdependencies between various resources, countries, and/or creations (MacNeill et al. 1991). Scientific and religious scholars are likely to agree that the universe is based on this core concept of creations, which are the environmental components, and interdependent on one another for survival and prosperity (Corral-Verdugo et al. 2008). Vatn (2000) argues that without the acknowledgement of interdependencies between human and nature, the environment would be viewed as a commodity for human purpose as compared to a stewardship approach. Furthermore, the interdependency between natural resources and economic resources is also highly established in the literature (Folke and Kåberger 2013). The National Environmental Policy Act (1970) highlights the notion of examining "cumulative impacts" of actions (Thatcher, 1990). The whole essence of closed loop economics highlights the need for products to be designed in a way that at the end of its life cycle it can become a core part of another product, reflecting interdependencies between stages of the product's life cycle. This concept is very much practiced in fields of agriculture as well as the alternative energy sector. On a more global scale, the concept of acknowledging interdependence is becoming the focus of climate change policies, which highlights how the survival of citizens from different countries is interdependent.

Figure 2 combines the four application principles with the aforementioned foundational principles of whys and whats (Figure 1) to present a comprehensive framework that defines the relationship between God, humankind, and the environment. This framework portrays the current scholarly wisdom on the Eco-Islam concept, and extends it with the application principles informed by our empirical analysis of the holy Qur'an. It should be noted that these four application principles are not mutually exclusive. They act to support each other and so offer a holistic approach with respect to Eco-Islam. 


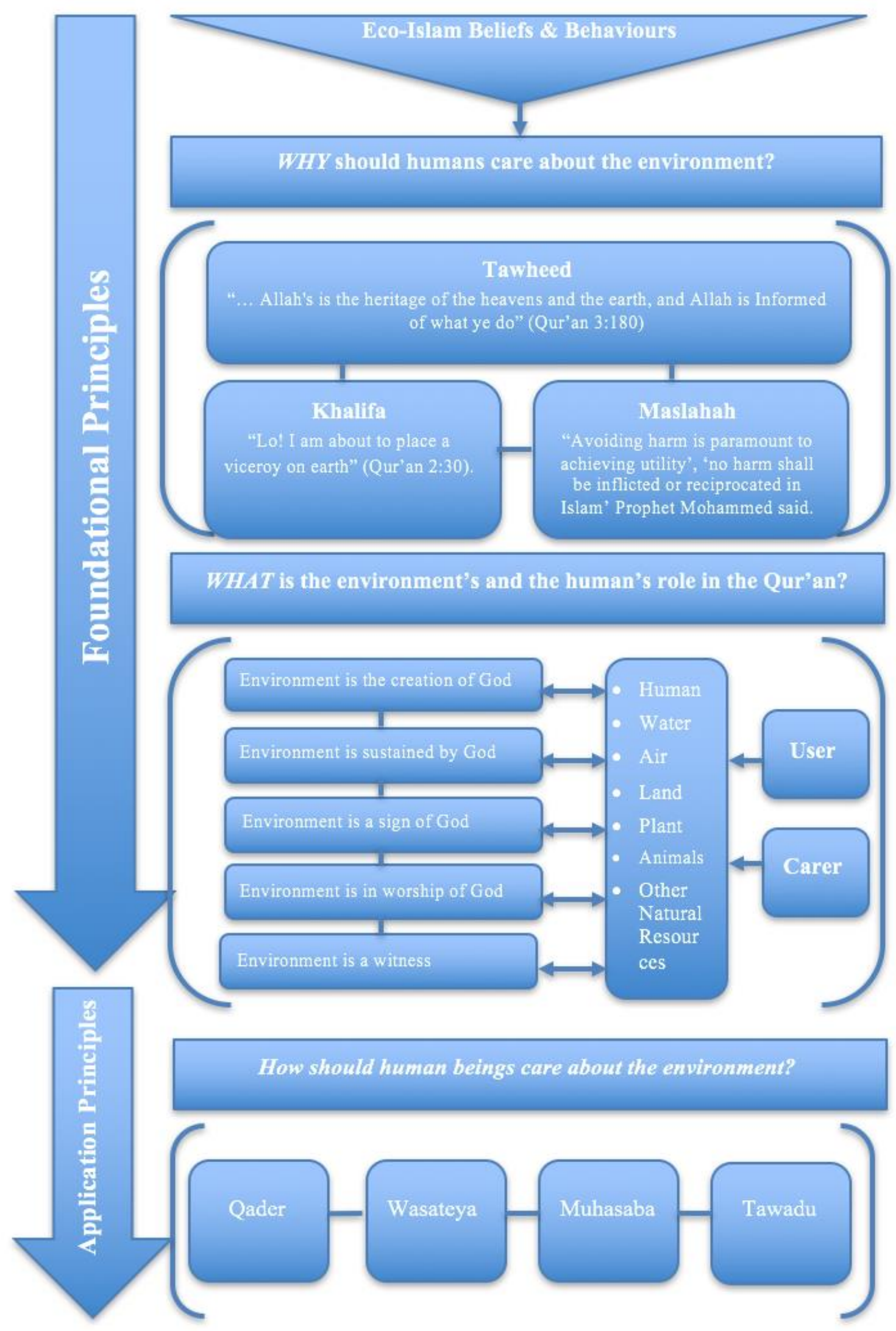

Figure 2: Eco-Islam Framework 


\section{Relevance of the Eco-Islam Principles to Industry}

This section is dedicated to presenting selected exemplary industries that show potential where the proposed Eco-Islam framework can be applied and extended in the business context as a foundation for policy formulation. We provide a summary of the current faith-based relevant initiatives in the sectors of farming, wildlife conservation, and finance (based on their environmental risk level from high to low) in order to highlight the complementary nature of the framework to the marketplace. This is in light of our acknowledgment of the significant gap that exists between Islamic teachings and the environmental practices of many organizations in Muslim markets (Abdelzaher and Abdelzaher, 2015).

\section{Farming}

The link between Islamic principles in the financial sector is well established in the marketplace. However, the leveraging of Islamic principles on farming ethics is significantly less developed, despite the dire need for a paradigm shift within agricultural practices (Shabbir et al. 2009), which can be attained by drawing on religious beliefs and practices. A recent report by the United Nations (2012) on sustainable agricultural practices documented the worsening state of land degradation and threats to food security, particularly in Africa - some of which is caused by current unsustainable farming practices (Pretty 1999). Compared to other industries, the act of farming presents spiritual significance in most religions but it also tends to rely more on the judgement of farmers than regulative bodies, making ethical judgment of the farmer very influential on outcomes (James and Hendrickson 2008). Therefore, the adoption of Eco-Islam principles in this industry would be appropriate. The Alliance of Religions and Conservation has recently launched Islamic Farming: A Manual for Conservation Agriculture, as "a new curriculum that integrates Qur'anic scriptures and teachings about caring for the Earth as a religious responsibility with practical training in conservation agriculture". ${ }^{3}$

A growing number of farms are associating their operations with "Islamic" principles or practice. Some of these farms include The Good Tree Farm of New Egypt located in Texas, USA, and Willowbrook Organic Farm in the UK, both of which embed Islamic agricultural ethics in their operations. For example, the owners of The Good Tree Farm said that "as Muslims, we believe that our fresh, local, organic food produced at our farm using sustainable agricultural practices that protect the environment and provide ecological stewardship will give our society the greatest benefit and make us a truly responsible business", (www.goodtreefarm.com). Similarly,

\footnotetext{
${ }^{3}$ For more details see http://www.arcworld.org/projects.asp?projectID=634.
} 
Willowbrook Organic Farm declared that "We ensure that the animals we rear for food are cared for, free from defect and raised naturally (not pumped full of chemicals and antibiotics)" (www.willowbrookorganic.org). Similarly: "They ask you what is lawful (halal) for them. Say what is natural and wholesome (Tayib) is lawful (halal) for you" (Qur'an 5:4). "We believe the raising of our animals is just as important as the dispatch, and as Muslims we concentrate on the rearing of our animals in a welfare friendly and environmentally sustainable manner" (www.willowbrookorganic.org). Also, an Indian faith-based Farm, Shaaz Organic Farms, "aims to spread the knowledge of agriculture and its need to next generation using the available resources and modern techniques, promoting the concept of Islamic Farming in India for Muslim farmers" (www.shaazorganicafarms.com/About-us).

Interestingly, a significant number of these farms reside in non-Muslim majority markets, which highlights the relevance of the proposed Eco-Islam principles to Muslim and non-Muslim majority contexts. Their activities range from raising cattle, poultry, and crops to a broader scope, such as serving as spiritual or healing retreat centres. For example, the Canadian Farm, Ontario Halal Farm, is committed to "producing Halal meat according to Sharia law through close working relationships with local farmers and suppliers, giving us a unique base from which to reaffirm our skill to consistently deliver quality product for value" (www.ontariohalal.com/about-us). With the increasing demand for more halal and organic food under the umbrella of responsible farming, there is the potential for more farms to adopt the proposed application principles to guide their operational policies. Perhaps conducting training programmes aiming at educating farmers in these markets on the relevance and importance of the application principles to their religious teachings, could actually encourage more environmentally conscious behaviours, as well as making sound business sense (e.g. Iyer 2009; Maloni and Brown 2006; Videras et al. 2012). In similarity to the ancient organic farming system, the Islamic farming system "is primary aimed at cultivating the land and raising crops in such a way, as to keep the soil alive and in good health by use of organic wastes (crop, animal and farm wastes, aquatic wastes) and other biological materials along with beneficial microbes (biofertilizers) to release nutrients to crops for increased sustainable production in an ecofriendly pollution free environment" (www.shaazorganicafarms.com/About-us).

\section{Wildlife and Marine Conservation Projects}

For organisations in the wildlife preservation sectors, the issue of practicing environmental ethics is critical. Wildlife faces survival risks created by human misuse of natural resources. While litigations and monetary fines are traditional mechanisms for prohibiting such actions, they have 
not proven a deterrent to the abuse of the environment, which emphasises the promotion of environmental ethics. The Eco-Islam comprehensive framework can also serve as a foundation for policy formulations for organisations that aim to preserve natural wildlife across the globe. History has shown that such initiatives are promising and can be a suitable target for the application of this framework. An example of this includes the world's first Islamic conservation guide launched by IFEES and the Directorate of Fisheries in Zanzibar in 1999. This innovative guide for protecting marine life used lessons from the Islamic Ecological Paradigm (IEP) to teach fishers how vital marine resources should be used, and protected and prohibited them from using unsustainable practices, including dynamite fishing, resulting in the depletion of fish stocks and other marine resources. This project was designed to protect Hima in accordance with the Islamic conservation principles, and promote a modified form of Hisba (i.e. accountability) to ensure compliance of the IFEES guide. This IFEES conservation guide was accepted by WWF International as a part of the Global Sacred Gifts for a Living Planet Programme.

A similar project that can benefit from this framework is that of Jabal Aja, also known as the greatest concentration of biological diversity in the interior of the Arabian Cape. It is located west of the town of Ha'il in north central Saudi Arabia and is managed by the National Commission for Wildlife Conservation and Development (NCWCD). This initiative aims at applying the provisions of Islamic law to protect this area and to set an example to the rest of the Muslim countries for the regeneration of wildlife habitats, as well as safeguarding of the main existing wildlife types (e.g., Nubian Ibex, Arabian Wolf, Idmi Gazelle, and dispersion of native plants and animals into the surrounding region).

\section{Green Finance/Investment}

The finance sector has been the industry most infiltrated by Islamic principles that shape investors' decisions. There is a growing base for more environmentally compliant investments. Recently, the Securities Commission Malaysia (SC) launched the Sustainable and Responsible Investment (SRI) Sukuk framework (2014) to facilitate the financing of sustainable and responsible investment initiatives. Datuk Ranjit Ajit Singh, Chairman of the SC said:

The introduction of the SRI sukuk framework is part of the SC's developmental agenda to facilitate the creation of an eco-system conducive for SRI investors and issuers and is also in line with the rising trend of green bonds and social impact bonds that have been introduced globally to facilitate and promote sustainable and responsible investing. Combined with Malaysia's leading position in the global sukuk market, this framework will further enhance the country's value proposition as a centre for Islamic finance and sustainable investments. 
(Retrieved from: https://www.sc.com.my/post_archive/sc-introduces-sustainableand-responsible-investment-sukuk-framework/)

Similarly, in April 2014, the Dubai Supreme Council of Energy, a government planning body, and the World Bank, signed an agreement to develop funding for the Emirates Green Investment Programme, including "green" Islamic bonds (Dorsman et al. 2016, p. 4). Similarly, Bank Muamalat Indonesia highlighted their commitment to improve the quality of people's lives by designing and implementing programmes with emphasis on four group activity aspects, namely (i) environment, (ii) social development, (iii) employment, occupational health and safety, and (iv) responsibility to the consumer (Annual Report 2015, p. 333).

\section{Relevance of the Eco-Islam Principles to other Abrahamic Faiths}

The Qur'an was revealed through Prophet Mohammed to all humankind. There are many Qur'anic verses where God explicitly talks to humankind and for humankind, for example:

And We have sent you (O Muhammad SAW) not but as a mercy for the 'Alamîn (mankind and jinn).

(Qur'an 21:107)

Verily, this (the Qur'ân) is no less than a Reminder to (all) the 'Alamîn (mankind and jinn).

(Qur'an 81:27)

(This is) a Book which We have revealed unto you (O Muhammad SAW) in order that you might lead mankind out of darkness (of disbelief and polytheism) into light (of belief in the Oneness of Allâh and Islâmic Monotheism) by their Lord's Leave to the Path of the All-Mighty, the Owner of all Praise.

(Qur'an 2:1)

As the term "monotheistic" suggests, Judaism, Christianity, and Islam share the foundational principle of Tawheed, implying the religious requirement that there is only one God to worship and the whole universe belongs to Him. The three religions also have a specific cosmology that defines the role of human beings in God's design for Creation, which has profound implications for the natural world. Chuvieco (2012, p. 10) argues that the role of human beings (leading vs. equal) among other creations in the universe "affects our sense of who we are in the universe, how we should relate with other species, and how we should use natural resources to make our life more equilibrated and sustainable", suggesting that solving the current environmental crises "is not only a matter of technology but also implies deep changes in our way of living [behavioural actions], which is in turn affected by our ethical or moral values [religious]". 
With this in mind, it can be argued that Islam follows similar considerations of Judeo-Christian on the pre-eminence of humans over other species, as the centre of the Creation. This tradition implies a shared belief that the natural world is created by God and made subject to humans for their moderate benefit (Chuvieco 2012). However, this dominant role of humans over other creatures is limited in two respects: humans are part of the natural world, and they are (theologically) entrusted by their God to care for and protect it, which is represented by the Khalifa principle in Islam. The analogy of the Khalifa principle is visible within the basic tradition of "environmental stewardship", which is the most standard approach among those Christians concerned with the environment (i.e. Christian Stewardship Ethics) (Attfield 2006; Kearns 1996), and increasingly promoted by the modern western church (Hope and Jones 2014), and referenced in the Torah and in comments on the sacred Scriptures by significant rabbis (Chuvieco 2012).

In line with pre-eminence of humans over other species and their Khalifa role, both humans (the most preferred creature by God) and other environmental elements (animals, plants, etc.) depend on God and on each other. As per the proposed framework, this concept is represented in the public good foundational principle (Maslahah), as well as in the interdependence application principle. Likewise, as noted by Chuvieco (2012), this religious tradition appears in several passages of the Bible and the Old Testament. He further added, following this tradition, if nature is affected by humans' irresponsible actions, the ideal equilibrium between human and nature vanishes, thus the earth produces various environmental crises. With this in mind, the relationship between humans and the environment should be reciprocal; i.e. human beings should not only acknowledge and maintain interdependence, but also promote mutual interaction with the environment, aiming to promote the public good by avoiding the anthropocentric arrogance of excessive, wasteful, and destructive use of environmental resources.

The environmental crises are common, and thus we argue that the responsibility to resolve them should be also. We strongly believe that, inspired by common denominators of the Abrahamic religions, the proposed Eco-Islam framework can be seen as a basis for change and guidance of sustainability policies in multiple sectors that aim to achieve environmental sustainability goals. For example, a recent World Bank report (Byerlee et al. 2013) on sustainable agriculture practices documented the worsening state of land degradation and threats to food security, particularly in the continent of Africa (Shabbir et al. 2009). Also, most of the Arab countries are suffering from an ecological deficit (Verner 2012). Such markets are in dire need of reassessing the extent to which their agriculture practices are sustainable, according to the WWF report 
(2010). The adoption of an Eco-Islam framework can enhance the level of commitment to environmental responsibility in the region - mostly characterised as religious communities.

The last two decades have witnessed some movements in the global community to create an ideally harmonious society with sustainable development, recognising the important role of religions in reaching those goals. For example, the Interfaith Declaration on Business Ethics was introduced in 1993 to outline the shared moral, ethical, and spiritual values found within all three Abrahamic religions, in order to create a number of (shared) principles/guidelines for international business behaviour (Interfaith Declaration 1993). More direct action has been taken by the Interfaith Declaration on Climate Change, which originated in 2009 with a vision to "tap into the huge potential of uniting humanity [religious (85\%) and non-religious (15\%)] behind the need to press the governments of Earth to take heed", calling for "the strongest possible climate treaty" (Interfaith Declaration on Climate Change 2009). Eco-Islam can be seen as a further step towards such ideally harmonious society with sustainable development.

\section{Conclusion}

This paper responds to the need for "a paradigm shift from belief to behaviour" to protect our motherland, the environment (Abdelzaher and Abdelzaher 2015; Islam 2012; Schwencke 2012). In particular, this paper has conceptually and methodologically advanced the prior literature on the relationship between the Islamic religion and environmental responsibility by presenting a comprehensive framework of Eco-Islam, informed by a thorough thematic analysis of the holy book of Qur'an. By picturing this religious (Islamic) relationship, the proposed Eco-Islam framework brings insights into both foundational principles (why and what environmental responsibilities matter) and application principles (how the environment should matter), thus guiding ethics and actual behaviours of human beings towards the environment.

The proposed framework envisages environmental responsibility as a moral, spiritual, and religious individual responsibility, thus complementing the existing corporate environmentalism approaches by connecting humans (i.e. Khalifa) with their God (principal/owner/creator) and with other creations (natural world elements - living and non-living). In Islam, as all creations are subject to God's laws, there should be no conflicting interests among individuals; everyone has a united life goal within the contexts of Tawheed, Khalifa, and Maslahah. With this in mind, we strongly argue that the proposed framework is not limited to the Islamic religion or Muslimmajority markets while its foundations is also visible in the basic traditions of other faiths, mainly monotheistic religions. 
We strongly argue that this framework can serve as a foundation for the development of organisational environmental policies and the enhancement of individuals' environmental ethics. Organisations that connect their sustainability goals to the understanding of the application principles are likely to be more effective in encouraging different stakeholders to comply with environmental best practices, as they can offer the whys, whats, and hows behind the desired environmental outcomes. In addition to policy development, these principles can also be used to measure performance towards sustainability goals. This is important as many organisations may communicate the need for sustainability but lack a framework to help them develop policies to achieve this goal. While organisations may develop formal penalties for reacting to poor environmental practices of their employees, there is also the significant untapped influence of a corporate culture that encourages best environmental practices. These proposed principles can be adopted as key corporate values, with the goal of nurturing a corporate culture that accurately understands the prescribed relationship between human actions and the natural environment.

While corporate citizenship behaviour relates to employees going the extra mile and adopting practices that are not necessarily part of their required responsibilities, we argue that the presented framework will help employees to more smoothly adopt the environmental best practices that are part of their responsibilities. We argue that there is value in adopting a religious framework that can be complementary to formal policies, and can be useful to companies facing difficulties with the adoption of best practices by all employees. Giving the employees the valuebased whys is likely to encourage a smoother adoption of corporate environmental standards. This, of course, does not rule out that such a culture can also encourage corporate citizenship behaviour where individuals do the extra mile to achieve environmental goals.

Although corporations' poor environmental practices continue to be a major cause of environmental pollution, individuals are the actors of these organisations; it is therefore important that research focuses directly on understanding the individual's side of the environmental equations. Research has shown that religious teachings have a direct impact on our behaviours, particularly as it relates to environmental ethics. Given the dire need for improved environmental behaviours, our investigation is timely in acknowledging what Islam teaches about environmental responsibility. We conducted a content analysis of the Qur'an to reveal specific foundation and application principles, answering the question of why and how individuals should adopt environmental stewardship.

As with other research, the current paper has two main limitations. First, the proposed framework has been built on a content analysis of one source of the Islamic law (i.e. the Qur'an). 
However, we have attempted, when appropriate, to support the discussion of the framework application principle by Hadiths (i.e. the second major source of Islamic law). Second, the adopted research process (i.e. thematic analysis) is naturally less objective, and therefore there is an inherent degree of subjectivity. However, this process is the most appropriate when studying an understudied topic in an explorative nature. However, two coders were used, and percentage of agreement was calculated/discussed and then mutually agreed.

Future studies can also use the proposed framework to develop operational policies and best practices to guide the environmental behaviours of individuals across organisations. It would be interesting to also explore whether our framework fits the practices of other industrial pollutants. For example, the oil and gas industry has a direct impact on the environment and plays a prominent role in the economic development of many Muslim majority markets. Furthermore, the proposed principles can be used to tackle other important phenomena like water conservation, which is a popular topic within these markets. Future research could also explore more deeply the impact of religious beliefs on utilising and protecting the environment and its limited resources through the disclosure of environmental performance. Finally, while the whole globe shares the suffering from various ecological crises, there is an opportunity to study other religions in the context of core environmental issues of concern, aiming to further advance our proposed framework and develop a more eco-multi-faith framework.

\section{References}

Abdel Haleem, H. (1998). Introduction. In H. Abdel Haleem (ed.), Islam and the Environment, (pp. 5-10). Ta-Ha, London.

Abdelzaher, D., and Abdelzaher, A. (2015). Beyond environmental regulations: Exploring the potential of "Eco-Islam" in boosting environmental ethics within SMEs in Arab markets. Journal of Business Ethics (September), 1-15.

Abbasi, A., Rehman, K. and Bibi, A. (2010) Islamic Management Model. African Journal of Business Management 4(9), 1873-1882.

Abu-Tapanjeh, A. (2009). Corporate governance from the Islamic perspective: A comparative analysis with OECD principles. Critical Perspectives on Accounting 20(5), 556-567.

Abu-Znaid, S. (2006). Islam and management: What can be learned? Thunderbird International Business Review 48(1), 125-139.

Adams, R. (1990). The greening of consumerism. Accountancy 105(1162), 81-83.

Al-Ghazali, A. (1901). Al-mustasfa min 'ilm al-usul. Al-Matba’ah Al-Amiriyyah, Cairo.

Al-Ghazali, M. (1998). Al-Mustasfa min ‘ilm al-usul. Dar al-Kutub al-Islamiyyah, Beirut.

Al-Juwayni, A. (1979). Al-burhan fi usul al-fiqh. Dar Al-Ansar, Cairo.

Al-Najjar, U. (2008). Maqasid al-Shari'ah bi ab'adin jadidah. Dar Al-Gharb Al-Islami, Beirut.

Al-Sabouny, M. A. (1978). Safawt altafaseer: Tafseer Qur'an karim. Dar Al-Sabouny (printing and publication), Cairo. 
Al-Qaradawi, Y. (2000). Safeguarding the environment in Islamic Sharia. Dar Al Khaleej.

Ali, A. J. (2010). Islamic challenges to HR in modern organizations. Personnel Review 39(6), 692-711.

Alserhan, B. (2015). The principles of Islamic marketing. Gower Publishing Limited, Surrey, UK.

Ansari, A., and Jamal, P. (2001-2002). Towards an Islamic jurisprudence of environment: An expository study. Religion and Law Review, X-XI (11-12), 80-103.

Ansari, A., Jamal, P., and Oseni, U. (2012). Sustainable development: Islamic dimension with special reference to conservation of the environment. Advances in Natural and Applied Sciences 6(5), 607-619.

Attfield, R. (2006). Environmental sensitivity and critiques of stewardship. In R. J. Berry (ed.), Environmental stewardship (pp. 76-91). T\&T Clark International, London.

Babcock, H. (2009). Global climate change: A civic republican moment for achieving broader changes in environmental behaviour. Pace Environmental Law Review 26(1), 1-18.

Bagader, A. A., El-Sabbagh E. E. M., Al-Gayand, A., Samarrai, M. U. I. and Llewellyn, O. A. (1994). Environmental protection in Islam. IUCN Environmental Policy and Law Paper No. $20 . \quad$ Retrieved $11^{\text {th }} \quad$ January 2017 from http://cmsdata.iucn.org/downloads/eplp_020reven.pdf.

Banerjee, S. (2002). Corporate environmentalism: The construct and its measurement. Journal of Business Research, 55(3), 177-191.

Bank Muamalat Indonesia (2015). Annual Report 2015. Retrieved 10th October, 2016 from http://www.bankmuamalat.co.id/uploads/hubungan_investor/2_annual-report2015_20160623125348.pdf.

Barney, J. B. and Hesterly, W. S. (2008). Strategic management and competitive advantage: Concepts and cases. Pearson/Prentice Hall, Upper Saddle River, NJ.

Beck, U. (1992). Risk society: Towards a new modernity. SAGE, London.

Beck, U. (1999). World risk society. Polity Publications, Cambridge, UK.

Beekun, R. (1996). Islamic Business Ethics. IIIT, Herdon, VA.

Brammer, S., Williams, G., and Zinkin, J. (2007). Religion and attitudes to corporate social responsibility in a large cross-country sample. Journal of Business Ethics 71(3), 229-243.

Braun, V. and Clarke, V. (2006). Using thematic analysis in psychology. Qualitative Research in Psychology 3(2), 77-101.

Bubna-Litic, D. (2009). Spirituality and corporate social responsibility - Interpenetrating worlds. Gower Publishing Limited, UK.

Byerlee, D., Garcia, F., Giertz, A., Palmade, V., and Palmade, V. (2013). Growing Africa Unlocking the potential of agribusiness. World Bank, Washington, DC. Retrieved $11^{\text {th }}$ January 2017 2017 from http://documents.worldbank.org/curated/en/2013/03/17427481/growing-africa-unlockingpotential-agribusiness-vol-1-2-main-report

Campbell, T. (2006). A human rights approach to developing voluntary codes of conduct for multinational corporations. Business Ethics Quarterly 16(2), 255-269.

Chapra, U. (1979). Objectives of the Islamic economic order. The Islamic Foundation, Leicester.

Chapra, U. (1992). Islam and the economic challenge. International Institute of Islamic Thought, Herndon, VA. 
Chuvieco, E. (2012). Religious approaches to water management and environmental conservation. Water Policy 14(S1), 9-20.

Corral-Verdugo, V., Carrus, G., Bonnes, M., Moser, G., and Sinha, J. B. (2008). Environmental beliefs and endorsement of sustainable development principles in water conservation toward a new human interdependence paradigm scale. Environment and Behavior 40(5), 703-725.

Cuomo, F., Mallin, C., and Zattoni A. (2016). Corporate governance codes: A review and research agenda. Corporate Governance: An International Review 24(3), 222-241.

Dewey, M. E. (1983). Coefficients of agreement. British Journal of Psychiatry 143(5), 487-489.

Dorsman, A., Arslan-Ayaydin, O., and Karan, M. (2016). Introduction: Energy and finance. In A. Dorsman, O. Arslan-Ayaydin, and M. Karan (eds), Energy and finance: Sustainability in the energy industry, (pp. ). Springer, Switzerland.

Dusuki, A. (2008). What does Islam say about corporate social responsibility? Review of Islamic Economics 12(1), 5-28.

Dusuki, A. and Abdullah, N. (2007). Maqasid al-Shari ah, Maslahah, and corporate social responsibility. The American Journal of Islamic Social Sciences 24(1), 25-45.

Dutton, Y. (1992). Natural resources in Islam, in Islam and Ecology. Edited by F. Khalid and J. O’Brien (1992), World Wide Fund for Nature, UK.

Eden, S. and Bear, C. (2011). Models of equilibrium, natural agency and environmental change: Lay ecologies in UK recreational angling. Transactions of the Institute of British Geographers. doi: 10.1111/j.1475-5661.2011.00438.x

Ekardt, F. (2009). The added value of the environment-ethical aspects of climate change. Journal of International Business Ethics 2(1), 46-58.

Farman, J. (1990). Halocarbons and stratospheric ozone - A warning from Antartica. In D. J. R. Angell, J. D. Comer, and M. L. N. Wilkinson (eds.), Sustaining earth: Response to the environmental threat, (pp. 71-78). Macmillan, London.

Faruqi, Y. M. (2007). Islamic view of nature and values: Could these be the answer to building bridges between modern science and Islamic science. International Education Journal 8(2), 461-469.

Folke, C. and Kåberger, T. (eds.) (2013). Linking the natural environment and the economy: Essays from the Eco-Eco group. Volume 1. Springer Science \& Business Media, Netherlands.

Gray, R., Kouhy, R., and Lavers, S. (1995). Corporate social and environmental reporting: A review of the literature and a longitudinal study of UK disclosure. Accounting, Auditing and Accountability Journal 8(2), 47-77.

Haneef, M. (1997). Islam, the Islamic worldview, and Islamic economics. IIUM Journal of Economics and Management, 5(1), 39-65.

Haniffa, R. M. (2001). Social responsibility disclosure: An Islamic perspective. University of Exeter working paper 01/04. ISSN 1473-2904.

Hasan, Z. (2006). Sustainable development from an Islamic perspective: Meaning, implications, and policy concerns. J.KAU: Islamic Economics 19(1), 3-18.

Hashim, U. (2010). Human resource management practices on organisational commitment: The Islamic perspective. Personnel Review 39(6), 785-799.

Hobson, I. (1998). Guiding principles for a solution to environmental problems. In H. Abdel Haleem (eds.), Islam and the environment, (pp. 33-42). Ta-Ha, London. 
Holsti, Ole R. (1969). Content analysis for the social sciences and humanities. Addison-Wesley, Reading, MA.

Hope, A., and Jones, C. (2014). The impact of religious faith on attitudes to environmental issues and Carbon Capture and Storage (CCS) technologies: A mixed methods study. Technology in Society 38, 48-59.

Hossain, D. (2014). Sustainable development and Islam: Is religious teaching invalid? Middle East Journal of Business 9(1), 10-17.

Hsieh, N. (2004). The obligations of transnational corporations: Rawlsian justice and the duty of assistance. Business Ethics Quarterly 14(4), 643-661.

Hui, L. (2008). Combining faith and CSR: A paradigm of corporate sustainability. International Journal of Social Economics 35(6), 449-465.

Ibrahim, S. H. (2000). The need for Islamic accounting; perceptions of its objectives and characteristics by Malaysian Muslim accountants and accounting academics. Ph.D. Thesis, Department of Accountancy and Business Finance, University of Dundee.

Interfaith Declaration - Code of Ethics on International Business. (1993). Retrieved $11^{\text {th }}$ January 2017

from http://repository.berkleycenter.georgetown.edu/921130InterfaithDeclarationCodeEthicsBus iness.pdf

Interfaith Declaration on Climate Change. (2009). Retrieved $11^{\text {th }}$ January 2017 from http://www.interfaithdeclaration.org/download/idcc_english.pdf

ISESCO. (2002). Islamic declaration on sustainable development. Retrieved $11^{\text {th }}$ January 2017 from http://www.isesco.org.ma/wp-content/uploads/2015/05/Islamic-Declaration-forSustainable-Development.pdf.

Islam, M. S. (2012). Old philosophy, new movement: The rise of the Islamic ecological paradigm in the discourse of environmentalism. Nature and Culture 7(1), 72-94.

Iyer, A. (2009). Corporate social responsibility and farmer suicides: A case for benign Paternalism. Journal of Business Ethics 85(4), 429-443.

Jalil, A. (2006). The significances of Maslahah concept and coctrine of Maqasid (objectives) AlShari'ah in project evaluation. The Journal of Muamalat and Islamic Finance Research 3(1), 171-202.

James, H. and Hendrickson, M. (2008). Perceived economic pressures and farmer ethics. Agricultural Economics 38(3), 349-361.

Jones, M. J. (2010). Accounting for the environment: Towards a theoretical perspective for environmental accounting and reporting. Accounting Forum 34(2), 123-183.

Jusoff, K. and Abu Samah, S. A. (2011). Environmental sustainability: What Islam propagates. World Applied Sciences Journal 12(special issue), 46-53.

Kamla, R. (2015). Critical Muslim intellectuals' thought: Possible contributions to the development of emancipatory accounting thought. Critical Perspectives on Accounting 31(September), 64-74.

Kamla, R., Gallhofer, S., and Haslam, J. (2006). Islam, nature and accounting: Islamic principles and the notion of accounting for the environment. Accounting Forum 30(2), 245-265.

Kamali, M. (1989). Source, nature and objectives of Sharicah. The Islamic Quarterly 33, 215234.

Kearns, L. (1996). Saving the Creation: Christian environmentalism in the United States. Sociology of Religion 57(1), 55-70. 
Kersten, C. (2011). Cosmopolitans and heretics: New Muslim intellectuals and the study of Islam. Hurst \& Company, London.

Khalid, F. (2002). Islam and the environment. In P. Timmerman, Social and Economic Dimensions of Global Environmental Change, (Vol. 1, pp. 332-339), Encyclopedia of Global Environmental Change. John Wiley \& Sons, Ltd.

Khalid, F. (2008). The environmental crisis and modernity: An Islamic perspective. Islamic Perspective 1, 40-45.

Khan, M. S. and Karim, N. (2010). Corporate social responsibility: Contemporary thought and Islamic perspectives. Thoughts on Economics, 21(1), 45-66.

Kovel, J. (2007). The enemy of nature: The end of capitalism or the end of the world? Zed Books, London.

Krippendorf, K. (1980). Content analysis: An introduction to its methodology. SAGE, London, pp.

Kula, E. (2001). Islam and environmental conservation. Environmental Conservation 28(1), 1-9.

Leitch, C. M., Hill, F. M., and Harrison, R. T. (2009). The philosophy and practice of interpretivist research in entrepreneurship quality, validation, and trust. Organizational Research Methods 13(1), 67-84.

Lewis, M. (2001). Islam and accounting. Accounting Forum 25(2), 103-127.

MacNeill, J., Winsemius, P., Yakushiji, T., and Trilateral Commission. (1991). Beyond interdependence: The meshing of the world's economy and the earth's ecology. Oxford University Press, New York.

Maloni, M., and Brown, M. (2006). Corporate social responsibility in the supply chain: An application in the food industry. Journal of Business Ethics 68(1), 35-52.

Mori, A. S. (2011). Ecosystem management based on natural disturbances: Hierarchical context and non-equilibrium paradigm. Journal of Applied Ecology 48, 280-292. doi: $10.1111 / \mathrm{j} .1365-2664.2010 .01956 . x$

Naqvi, S. (1981). Ethics and economics: An Islamic synthesis. Islamic Economic Series 2. The Islamic Foundation, Leicester.

Naqvi, S. (1997). The dimensions of an Islamic economic model. Islamic Economic Studies $4(2), 1-23$.

Naqvi, S. (2003). Perspectives on morality and human well-being: A contribution to Islamic economics. The Islamic Foundation, Leicester.

Naseef, A. (1998). The Muslim declaration on nature. In H. Abdel Haleem (ed.), Islam and the environment, (pp. 12-15). Ta-Ha, London.

Nasr, S. (1967) Man and nature: The spiritual crisis in modern man. ABC International Group, Inc, Chicago.

Owen, A. and Videras, J. (2007). Culture and public goods: The case of religion and the voluntary provision of environmental quality. Journal of Environmental Economics and Management 54(2), 162-180.

Ozdemir, I. (2003). Towards an understanding of environmental ethics from a Qur'anic perspective. $\quad$ Retrieved $11^{\text {th }} \quad$ January 2017 from https://www.scribd.com/doc/23750719/Environmental-Ethics-from-a-Qur-anic-Perspective

Peace, R. (2006) Accountants and a religious covenant with the public. Critical Perspectives on Accounting 17(6), 781-797. 
Platonova, E. (2013). Corporate social responsibility from an Islamic moral economy perspective: A literature survey. Afro Eurasian Studies 2(1-2), 272-297.

Porter, M. E., and Reinhardt, F. L. (2007). A strategic approach to climate. Harvard Business Review 85(10), 22-26.

Pretty, J. (1999). Regenerating agriculture: Policies and practice for sustainability and selfreliance. Earthscan, London.

PricewaterhouseCoopers. (2013). Islamic finance: Creating value. Retrieved $11^{\text {th }}$ January 2017 from https://www.pwc.com/m1/en/publications/islamic_finance_capability_statement.pdf

Rice, G. (1999). Islamic ethics and the implications for business. Journal of Business Ethics 18(4), 345-358.

Roughton, G. (2007). The ancient and the modern: Environmental law and governance in Islam. Columbia Journal of Environmental Law 32, 99-139.

Saeed, M., Ahmed, Z., and Mukhtar, S. (2001). International marketing ethics from an Islamic perspective: A value-maximization approach. Journal of Business Ethics 32(2), 127-142.

Salem, M., Hasnan, N., and Osman, N. (2012). Some Islamic views on environmental responsibility. 2012 2nd International Conference on Environment Science and Biotechnology, 22nd-23rd December 2012, Kuala Lumpur, Malaysia. IPCBEE Vol. 48. IACSIT Press, Singapore. doi: 10.7763/IPCBEE.

Schneider, S. H. (1990). The changing climate and problems of prediction. In D. J. R. Angell, J. D. Comer, and M. L. N. Wilkinson (eds), Sustaining earth: Response to the environmental threat, (pp. 33-42). Macmillan, London.

Schwencke, A. (2012). Globalized Eco-Islam: A survey of global Islamic environmentalism. LIRS, Leiden University. Retrieved $11^{\text {th }}$ January 2017 from http://media.leidenuniv.nl/legacy/report-globalized-eco-islam-a-survey-schwencke-vs-24february-2012-pdf.pdf.

Shabbir, S. A., D'Silva, J., and Behnassi, M. (2009). The integration of sustainable agriculture, rural development and ecosystems in the context of climate change, the energy crisis and food insecurity. Agadir International Conference, $12^{\text {th }}-14^{\text {th }}$ November, Agadir, Morocco.

Smith, M. and Taffler, R. J. (2000). The chairman's statement: A content analysis of discretionary narrative disclosures. Accounting, Auditing and Accountability Journal 13(5), 624-646.

Stern, N. (2006). The economics of climate change. The Stern review. Cambridge University Press, UK.

Thatcher, T. L. (1990). Understanding interdependence in the natural environment: Some thoughts on cumulative impact assessment under the National Environmental Policy Act. Environmental Law 20, 611.

Trucost. (2010) What we do. Retrieved $11^{\text {th }}$ January 2017 from http://www.trucost.com/whatwe-do.

Uddin, S. (2003). Understanding the framework of business in Islam in an era of globalization: A review. Business Ethics: A European Review 12(1), 23-32.

United Nations. (2012). Food and agriculture: The future of sustainability. Retrieved $11^{\text {th }}$ January 2017 from https://sustainabledevelopment.un.org/content/documents/agriculture_and_food the future of_sustainability_web.pdf.

Vatn, A. (2000). The environment as a commodity. Environmental Values 9(4), 493-509. 
Verner, D. (ed.). (2012). Adaptation to a changing climate in the Arab countries: A case for adaptation governance and leadership in building climate resilience. World Bank Publications, Herndon, VA. Retrieved $11^{\text {th }}$ January 2017 from http://www.ebrary.com

Videras, J., Owen, A., Conover, E., and Wu, S. (2012). The influence of social relationships on pro-environment behaviors. Journal of Environmental Economics and Management 63(1), $35-50$.

Wilkinson, M. and Woodin, S. (1990). Acid precipitation. In D. J. R. Angell, J. D. Comer, and M. L. N. Wilkinson (eds), Sustaining earth: Response to the environmental threat, (pp. 3342). Macmillan, London.

Williams, G. and Zinkin, J. (2010). Islam and CSR: A study of the compatibility between the tenets of Islam and the UN Global Compact. Journal of Business Ethics 91(4), 519-533.

Wills, C. (2013). Green equilibrium: The vital balance of humans \& nature. Oxford University Press, UK.

WWF. (2010). Sustainable agriculture: Links to international development. WWF-UK. Retrieved 11th October, 2016 from http://assets.wwf.org.uk/downloads/wwf_sustainable_agriculture_briefing.pdf.

Yasmin, S., Haniffa, R., and Hudaib, M. (2014). Communicated accountability by faith-based charity organisations. Journal of Business Ethics 122(1), 103-123.

Zbidi, M. (2013). The call to Eco-Jihad. Retrieved $11^{\text {th }}$ January 2017 from https://en.qantara.de/content/islamic-environmentalism-the-call-to-eco-jihad

Zinkin, J. (2007). Islam and CSR: A study of the compatibility between the tenets of Islam, the UN global compact and the development of social, human and natural capital. Corporate Social Responsibility and Environmental Management 14(4), 206-218. 